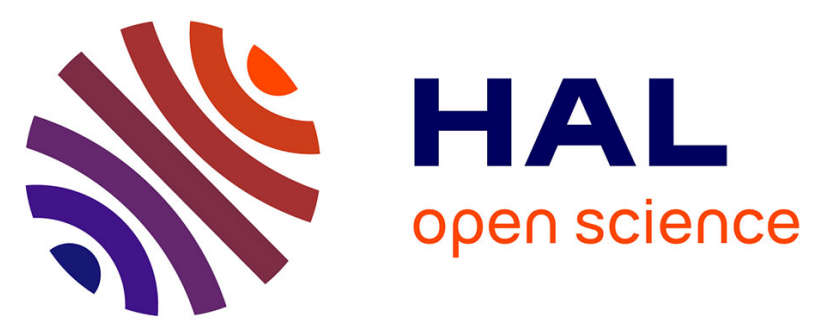

\title{
Small can be beautiful for organic market gardens: an exploration of the economic viability of French microfarms using MERLIN
}

\author{
Kevin Morel, Magali San Cristobal, François Gilbert Léger
}

\section{To cite this version:}

Kevin Morel, Magali San Cristobal, François Gilbert Léger. Small can be beautiful for organic market gardens: an exploration of the economic viability of French microfarms using MERLIN. Agricultural Systems, 2017, 158, pp.39-49. 10.1016/j.agsy.2017.08.008 · hal-01608929

\author{
HAL Id: hal-01608929 \\ https://hal.science/hal-01608929
}

Submitted on 15 Sep 2020

HAL is a multi-disciplinary open access archive for the deposit and dissemination of scientific research documents, whether they are published or not. The documents may come from teaching and research institutions in France or abroad, or from public or private research centers.
L'archive ouverte pluridisciplinaire HAL, est destinée au dépôt et à la diffusion de documents scientifiques de niveau recherche, publiés ou non, émanant des établissements d'enseignement et de recherche français ou étrangers, des laboratoires publics ou privés. 


\title{
Small can be beautiful for organic market gardens: An exploration of the economic viability of French microfarms using MERLIN
}

To cite: Morel, K., San Cristobal, M., Léger, F., 2017. Small can be beautiful for organic market gardens: An exploration of the economic viability of French microfarms using MERLIN. Agricultural Systems, (158): 39-49.

\begin{abstract}
Microfarms are commercial soil-based market gardens cultivating organic vegetables with less than 1.5 ha per farmer in rural France. Microfarms typically grow crops in both outdoor and protected (tunnel) areas. Despite their growing popularity among young farmers with no agricultural background, there are no data on expected income generated by these small-scale farms. Our objective was to determine the economic viability generated by a given agricultural area based on distinct microfarm scenarios. We used the stochastic model MERLIN to simulate 18 microfarm scenarios combining three technical systems (varying with respect to the mechanization level, use of commercial inputs, cropping density, and number of cropping cycles per year), two marketing strategies (varying with respect to the length of the selling period and the range of crops grown), and three investment hypotheses (varying with respect to the level of bank loans and the percentage of workload used for self-built equipment). Viability was calculated from the number of simulations that generated a selected minimum monthly income $(600,1,000$, or 1,400 Euro) for a maximum annual workload $(1,800$ or 2,500 h).

This study shows that organic microfarms can be made economically viable in some cases but that the risks of not reaching viability in microfarms are not to be neglected. For microfarms, system redesign based on low mechanization, higher cropping density, more cropping cycles per year, low-input practices, lower fixed costs, and lower initial investment (manual and biointensive system with tiller cultivation) was more favorable (meaning a higher modeled viability) than input substitution (classic system) at a small scale. A 9-month selling period without winter storage crop cultivation led to higher viability than a 12-month selling period with winter storage crop cultivation. Low-cost investment strategies based on self-built equipment and second-hand materials led to lower viability than high-cost investment strategies that purchased equipment because the low-cost strategies increased the workload. Further research on microfarms should integrate other types of production and activities, such as smallscale breeding and on-farm processing and examine in which extent collaborations between microfarmers and larger scale farms could contribute to reshape farming systems and impact rural communities beyond the gate of microfarms.
\end{abstract}

Keywords: Agroecology, Short supply chains, Permaculture, Urban agriculture, Small farms; System redesign

\section{INTRODUCTION}


In northern countries, the ever growing industrialization of agriculture leads to a constant increase in farm size to counterbalance the decreasing margins caused by higher costs of external inputs and new technology (Van der Ploeg, 2010). Industrialization of agriculture brings specialization, landscapes simplification, dependency to global markets, and disconnection from local food needs. Its negative impacts on the environment have been largely demonstrated (e.g., Stoate et al., 2009). In reaction, increasingly strong social movements are campaigning to develop food systems that preserve natural resources and contribute to the vitality of local communities (Holt Giménez and Shattuck 2011; Fernandez et al. 2013). Calling for a shift from the industrial model, they often support farming at a "human scale" which is supposed to allow the implementation of environmentally sound agroecological practices, the creation of more jobs and the development of local short supply chains such as community supported agriculture (CSA). Within this trend, we coin as "microfarms" very small scale organic farms whose cultivated acreage is under official recommendations. Although specific statistical data for microfarms is lacking, they are gaining popularity in Europe and Northern America.

In rural areas, they attract a new generation of people with no agricultural background, who are not conditioned by conventional agricultural standards, and choose organic farming to act concretely for a "better world" and "reconnect with nature". As microfarms require limited acreage and a small initial investment, they seem ideal for these new - often young and idealistic - farmers, who lack the always increasing financial capital necessary to invest in larger farms (Van der Ploeg, 2010; Allens and Leclair, 2016).

In urban areas, more and more cities want to develop sustainable and local food systems integrating agriculture. This is the case for example of the more than hundred cities that have signed up for the Milan Urban Food Policy Pack (2016). Urban agriculture can take a diversity of forms such as community gardens, allotments, guerrilla gardening, rooftop gardens and greenhouses, aquaponics (Lovell, 2010). In this context, commercial microfarms are raising interest because their small scale seems particularly convenient in urban areas, where the access to land is restricted (Daniel, 2017).

Although microfarms are progressively attracting more consumers, alternative farmers and municipalities, their economic viability is more and more questioned. Our research objective was to investigate the economic viability of microfarms, which is a key factor of their sustainability and wider development.

We focused on Northern France where organic market gardening microfarms have gained widespread popularity (Fig.1). They have been characterized by Morel and Léger (2016) as organic farms where:

- Market gardening is the main income-earning activity. Crops are grown in soils in outdoor and protected areas (in cold tunnels), which excludes roof-top cultivation areas.

- The cultivated area is below 1.5 ha by full-time equivalent, which is the minimal size generally recommended by French official agricultural development agencies for diversified market gardening (GAB/FRAB, 2009).

- More than 30 crops are grown per farm to promote cultivated biodiversity. 
- Farmers sell their production through short supply chains: direct selling to consumers or with only one intermediary.

A recent study reported that one-third of 3000 new farms in France in 2013 were created by young people with no agricultural background. These new farmers are attracted by organic agriculture (63\% of them), short supply chains (58\%), and market gardening (23\%), which is their preferred type of production (Jeunes Agriculteurs, 2013). The farming strategies developed by microfarmers are highly diverse (Morel and Léger, 2016). In terms of technical system, some of them implement organic farming in a logic of input substitution, replacing conventional inputs with organic ones whereas other seek a global redesign of their system as historically promoted by organic agriculture (Rosset and Altieri, 1997; Darnhofer et al., 2010). Their marketing and investment strategies also differ which may strongly impact their income. Agricultural institutions and future farmers lack references regarding the economic viability of these different strategies. Microfarms are still atypical initiatives with little data available. This precludes statistical approaches to analyze their economic viability. We decided to use computational modeling to investigate a wide range of microfarm strategic scenarios following a logic of in silico experimentation (Martin et al., 2011).

In this paper, we present and discuss the implementation of the stochastic model MERLIN (Morel et al., under review) to explore the economic viability of 18 microfarm scenarios that combined three technical systems, two marketing strategies of direct selling, and three investment hypotheses. We performed 1000 simulations per scenario to account for the diversity of crop planning adapted to the direct selling of weekly vegetables boxes and the variability of yields and workload per crop observed on the field. We focused on rural microfarms because in France microfarms first started on the countryside. 
(a)

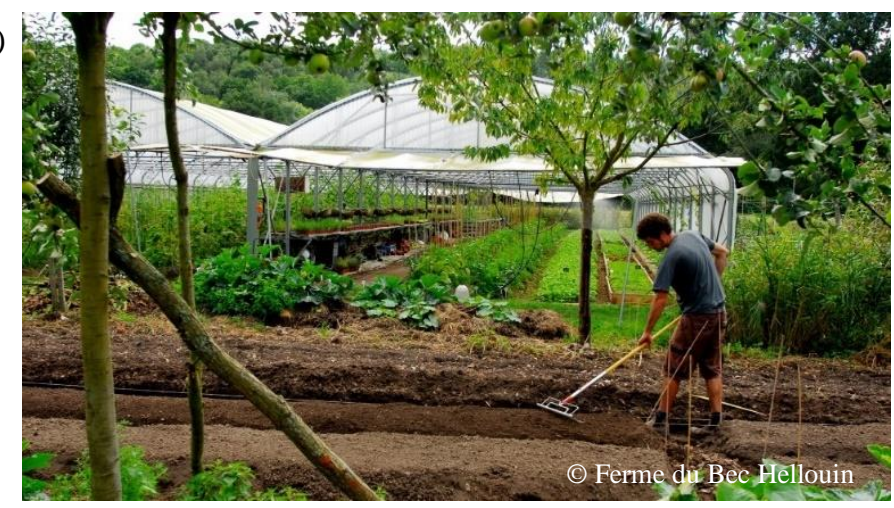

(b)

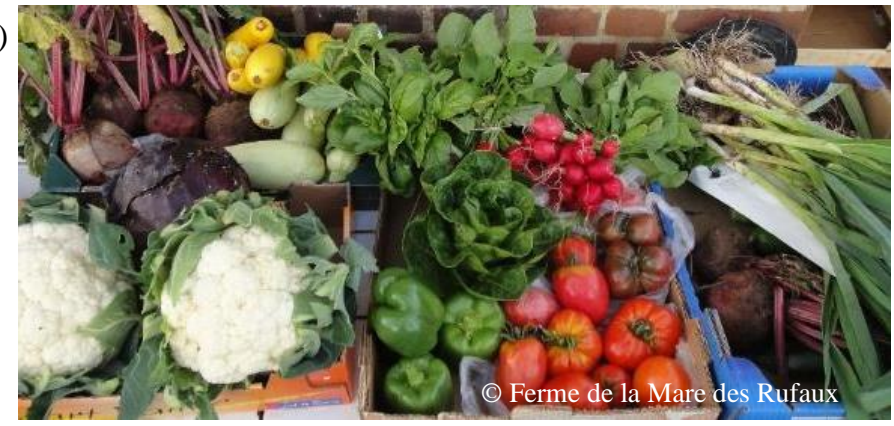

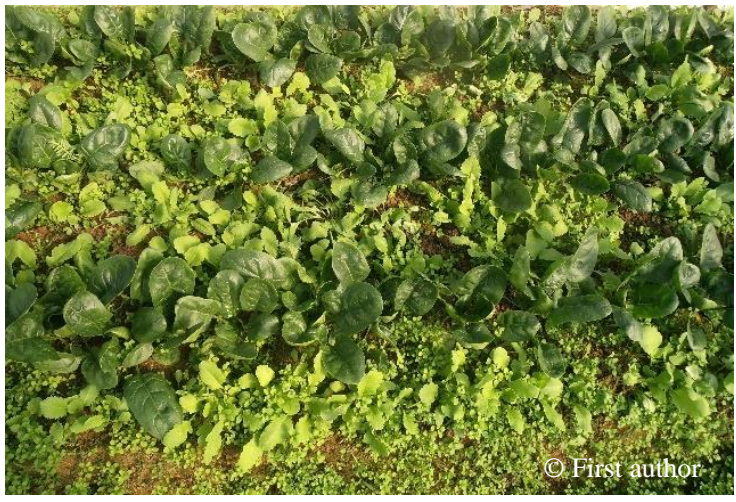

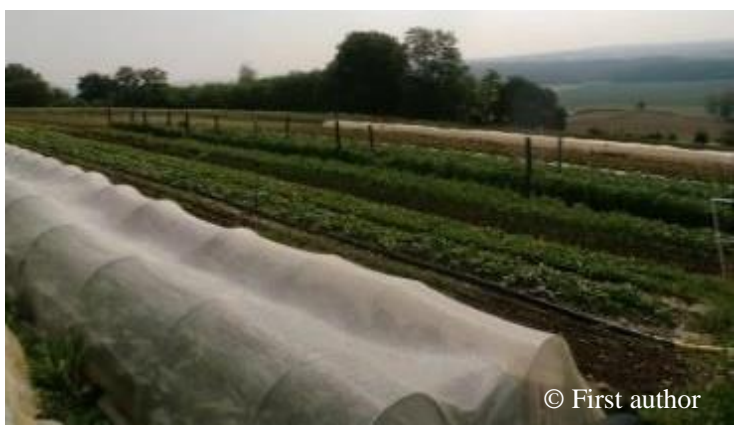

Fig. 1. Illustrations of rural microfarms and their produce in northern France. (a) Limited mechanization (here only manual labor). (b) High level of cultivated biodiversity directly sold to consumers in vegetables boxes. (c) High cropping density and intercropping of radishes and spinach. (d) Small scale (photo shows part of a farm of $8,000 \mathrm{~m}^{2}$ managed by a full-time microfarmer).

\section{MATERIALS AND METHODS}

\subsection{MERLIN: a model built from 20 microfarms in Northern France}

MERLIN is a static stochastic model developed by Morel et al. (under review), which enables simulations of the income and the utilized agricultural area (UAA) of a single microfarmer according to the farmer's annual workload and contrasting strategic scenarios. The MERLIN model was built and calibrated based on data collected from 20 microfarms in northern France. Given the small number of existing microfarms disabling the use of statistical or random sampling, the farms were selected according to theoretical sampling (Eisenhardt, 1989). This sampling ensured that they represented microfarm diversity in terms of variables that potentially affected yields, workload and costs: mechanization (manual, tiller, tractor), use of commercial inputs (low or high) and self-built equipment to reduce bank loans (present or absent). The cultivated acreage per full-time farmer ranged from 1200 to $12,000 \mathrm{~m}^{2}$. The farms were managed by one to three farmers, male or female, aged between 25 and 55, generally with a high level of education and a wide range of career paths. Only three farms were led by people with an agricultural background. The farms were created recently (3-12 years ago), which supports the recent emergence of these atypical farming systems. 
MERLIN considers two different climates, cold or mild, that affect the cropping cycles and determine which crops will be grown outdoors or in tunnels at different times of the year. According to different scenarios, MERLIN integrates the following parameters: (i) predictions of yields and workloads per unit area for 50 crops (including production, commercial, and administrative tasks); (ii) random combinations of 1053 possible cropping cycles (outdoors and in tunnels) to design yearly cropping plans that match the marketing criteria for weekly vegetable boxes in CSA schemes (satisfying quantity and diversity of crops throughout the marketing period); and (iii) prices of crops, subsidies, and variable and fixed expenditures (Morel et al., under review). MERLIN has been validated by more than 300 practitioners (farmers, agricultural teachers and advisors) from different regions of northern France and from independent data set (Morel and Léger, under review).

\subsection{Simulating 18 contrasting strategic scenarios with MERLIN}

Based on semi-directive interviews and discussions with the 20 microfarms of the sample, we built an expert-based typology of three categories of strategic choices whose impact was judged as potentially impacting farm viability: technical system, marketing and investment.

A scenario was defined as the combination of a technical system, a marketing strategy, and an investment hypothesis. We characterized three possible technical systems, two marketing strategies, and three investment hypotheses to explore contrasting microfarm scenarios $(3 \times 2 \times 3=18$ possible scenarios $)$.

\subsubsection{Technical systems}

We considered three technical systems along opposite gradients of (i) mechanization, (ii) low-input practices, and (iii) land-use objective (Fig.2).

Low-input practices aimed to replace commercial fertilizers and phytosanitary products and include a variety of practices to such as straw mulching, preparing farm-made phytosanitary decoctions, and composting animal manure freely available from local organic or conventional cattle breeders. Low-input practices also relied on using plants mainly propagated on farm rather than obtained commercially.

The manual system was designed to produce a large quantity of food on a small amount of land using only manual labor and permaculture principles, which promote farming without the use of petroleum products (Mollison and Holmgren, 1981; Hervé-Gruyer and Hervé-Gruyer 2016). The manual system relied on high cropping density and intercropping, which are only possible with manual labor. Intercropping consisted in growing two to five crops together which were carefully chosen to have complementary heights to maximize incident light, different rooting depths to maximize water and nutrient absorption, and different maturation times to limit competition between plants (De Liedekerke De Pailhe, 2014). The high land-use objective limited the growth of green manure, but other low-input practices were implemented.

The bio-intensive system was inspired by Coleman (1995) and Fortier (2014), and sought high productivity per unit through high cropping density and intensive crop successions. Labor efficiency was enhanced by using mechanization for superficial tillage (with a tiller). The biointensive system did not include intercropping because it was perceived as a source of 
complexity in crop management. Low-input practices were implemented and green manure was grown, which reduced the land-use objective compared with that of the manual system.

The classic system was inspired by common current farming practices in diversified organic market gardens in France, and was not designed to optimize land use. Mechanization was used for most cropping activities, except when harvesting was done by hand. Mechanized weeding required lower planting density. No intercropping or low-input ecological practices were implemented. Fertility and phytosanitary strategies were based primarily on commercial organic inputs, which corresponded with an approach of organic farming as input substitution rather than system redesign (Rosset and Altieri, 1997). Indeed, this system implemented conventional market gardening practices and only replaced conventional commercial inputs by organic ones.

\begin{tabular}{|c|c|c|c|}
\hline & $\begin{array}{l}\text { Manual } \\
\text { microagriculture }\end{array}$ & $\begin{array}{l}\text { Bio-intensive market } \\
\text { gardening }\end{array}$ & $\begin{array}{l}\text { Classic diversified market } \\
\text { gardening }\end{array}$ \\
\hline Mechanization & $\begin{array}{l}\text { Manual (superficial } \\
\text { tillage) }\end{array}$ & $\begin{array}{l}\text { Small mechanization } \\
\text { (tiller) only for superfical } \\
\text { tillage }\end{array}$ & $\begin{array}{l}\text { Tractor for most cropping } \\
\text { practices (including plowing } \\
\text { and weeding) expect some } \\
\text { hand harvest }\end{array}$ \\
\hline Cropping density & High & High & Low \\
\hline Intercropping & Yes & Yes & No \\
\hline Low-input practices & Yes & Yes & No \\
\hline Green manure & No & Yes & No \\
\hline $\begin{array}{l}\text { Land use objective (number of } \\
\text { cropping cycles per plot per } \\
\text { year) }\end{array}$ & 4 to 6 & 1 to 4 & 1 to 2 \\
\hline
\end{tabular}

\section{Low-input practices and} land use objective

Mechanization

Fig. 2. Characteristics of the three technical systems considered by MERLIN.

The variable costs represented $11 \%$ of sales in the manual and bio-intensive systems implementing low-input practices and $20 \%$ of sales in the classic system relying on commercial inputs. The fixed costs for a single farmer increased with the level of mechanization: 9,000 EUR in the manual system, 10,500 EUR in the bio-intensive system and 12,000 EUR in the classic system (Morel et al., under review).

\subsubsection{Marketing strategies}

We considered two marketing strategies for weekly sales of vegetable boxes in a CSA scheme. A marketing period of 12 months, in which farmers sold a wide range of crops throughout the year, including winter storage crops (Table 1). A marketing period of 9 months from April to December, in which farmers did not grow winter storage crops and used some of the winter for time off from work. The prices for the vegetables were the mean prices of the 20 microfarms used to create the model. These were not premium prices and allowed lower- and middle-income customers in rural areas to buy organic, fresh and locally produced vegetables from microfarms (Table 1). 


\subsubsection{Investment hypotheses}

One advantage of microfarms is that their small scale allows people with no or low initial capital investment to transition into farming. Our model considered that farmers had no initial capital and had to acquire 5-year bank loans to cover the initial investment. Three investment hypotheses were considered, which corresponded with two phases of farm life. In the low-cost setup, the farmer utilized self-built equipment based on second-hand material. This strategy reduced initial investment costs but increased the production workload. In the high-cost setup, the farmer purchased all required equipment. This strategy reduced the workload but increased the investment costs. In the running phase, all investment bank loans had been paid off (five years after setup). Investment costs and subsidies are detailed according to technical system and investment hypothesis in Morel et al. (under review). Globally, initial investment increased with the level of mechanization and were higher for the high-cost setup within a range from 15,000 to 45,000 EUR for fixed investment (water drilling, tools, delivery van and storage building, social security and insurance) and from 10 to 30 EUR per $\mathrm{m}^{2}$ of tunnels with irrigation. The land was bought at 0.5 EUR per $\mathrm{m}^{2}$. Farmers received fixed subsidies per farm $(2,755$ EUR per year), variable subsidies linked to the UAA (0.085 EURO per $\mathrm{m}^{2}$ ) and additional subsidies of 3,000 EUR per year only in the setup period.

\subsubsection{Running 1000 simulations per scenario}

A total of 1,000 simulations were run for each of the 18 scenarios because the average and median incomes and UAA stabilized after 600 to 850 simulations depending on the scenario. Each simulation randomly selected a climate (cold or mild), a cropping plan, and different values of the parameters affecting yields and workloads from within the range of variability allowed by each scenario (detailed in Morel et al., under review).

\subsection{Scenario evaluation and analysis}

\subsubsection{Calculating microfarm viability}

Based on discussions with farmers, we defined economic viability as the possibility to obtain a decent income from an acceptable level of workload. "Decent" and "acceptable" are subjective values that varied among the farmers depending on their world view, philosophy (relative importance of money and quality of life), and material needs (the number of individuals supported by the microfarm). The minimal monthly income in France is around 1,000 EUR but some farmers were ready to accept less in exchange for the quality of life and values they attached to organic farming, especially if they had no children. For other, it was not an option to earn less than 1,000 EUR because they had children or higher living standards. To accommodate this diversity, we considered three contrasting levels of minimal monthly income $(600,1,000$, and 1,400 EUR) and two levels of maximum annual workload (1,800 and 2,500 h). The three income constraints and two workloads constraints were combined to create six viability constraints. Economic viability (simply referred to as "viability" throughout this paper) was assessed for the six constraints as the ability to reach the minimum monthly income judged as decent without outreaching the maximum level of annual workload acceptable. This approach to viability as the possibility of a system to simultaneously satisfy different 
constraints, rather than seeking an optimal scenario that maximizes a set of criteria, was inspired by viability theory (Aubin, 1991). Viability theory is consistent with microfarmers' aspirations to reach satisfying levels of income and workload, rather than maximizing profit.

The viability of each simulation was assessed for the six viability constraints. The reported viability is the percent of simulations attached to one given scenario that respects the viability constraints, which reflects the possibility to obtain the given income and workload levels.

\subsubsection{Variables used to analyze the scenarios}

To analyze the viability of different scenarios, we used three intermediary variables given by MERLIN. The land productivity is the amount of sales (in EUR) per unit area of UAA $\left(\mathrm{m}^{2}\right)$. The land-use intensity is the amount of labor per unit area of UAA $\left(\mathrm{m}^{2}\right)$. The labor productivity is the amount of sales (in EUR) per unit labor. We also considered the mean yields and production workload per unit area for the 50 crops according to the given scenarios. For the simulations allowing viability, we calculated the UAA including footpaths between the cropping beds (20\% of UAA in tunnels and $35 \%$ of UAA outdoors) and the share of tunnels in UAA considering the maximum annual workload of 1,800 or $2,500 \mathrm{~h}$.

\subsubsection{Data analysis}

Data are expressed as means \pm standard deviation throughout. Statistical analysis was carried out with R (version 3.3.1). Pairwise comparisons of mean levels of labor productivity, land productivity, land-use intensity and utilized agricultural were performed with t-test with unequal variances across scenarios. The False Discovery Rate (FDR) was controlled with Benjamini and Hochberg (1995) approach at 5\%.

To analyze statistically the effects of all potential factors on viability (scenarios, climate, income and workload constraints), viability chances simulated by MERLIN were modelled with a generalized linear model (GLM) with binomial distribution and probit link. A forward variable selection procedure was used to assess the effects of factors based on Wald tests.

\section{RESUlts}

\subsection{Yields and production workload per crop according to scenarios}

The parameters utilized by MERLIN to predict yields and production workloads (Morel et al., under review) led to higher yields for the manual and bio-intensive technical systems because they did not implement mechanized weeding (Table 1). Mechanized weeding, implemented only by the classic system requires more space between crop rows, which reduced the cropping density and final total yield.

Higher cropping densities implemented by the manual and bio-intensive systems reduced the workload dedicated to weeding because weeds had less space to invade crops (Liebman and Davis, 2000). These two technical systems also tended to till the soil less frequently than the classic system. However, these two advantages of the manual and bio-intensive systems did not mitigate the increased workload due to low-input practices, which resulted in higher production 
workload per unit area for different crops. The bio-intensive system had lower production workload per unit area than the manual system because it used mechanization for tillage.

The low-cost investment setup increased the average production workload compared with that of the running phase presented in Table 1. This increase was due to the self-building of equipment which resulted in average to an increase of $67 \%$ of the production workload predicted by MERLIN (Morel et al., under review).

\subsection{Land-use intensity, labor, and land productivity}

At the farm scale, land productivity increased with land-use intensity because both of them increased with the number of cropping cycles linked to the land use objective of each scenario (Fig.3). The manual system resulted in higher land productivity and land-use intensity than the other two technical systems due to high cropping density, intercropping, and the highest landuse objective. The bio-intensive scenario led to the highest labor productivity. Its farming practices were the most efficient in terms of yields per labor invested by combining high cropping density and mechanization for tillage. Labor productivity in the classic system was slightly higher than that of the manual system.

The 9M marketing strategy excluded winter storage crops and led to higher land productivity and land-use intensity than the $12 \mathrm{M}$ marketing strategy. Winter storage crops had longer cropping cycles than other crops $(6.3 \pm 1.9$ months versus $4.7 \pm 1.8$ months, respectively). Winter storage crops also generated less sales per unit of cultivated acreage (7.7 $\pm 1.54 \mathrm{EUR} \mathrm{m}^{-2}$ versus $8.6 \pm 5.4 \mathrm{EUR} \mathrm{m}^{-2}$, respectively). This resulted in higher labor productivity in the 9 -month marketing strategy.

MERLIN calculates labor productivity $\left(\mathrm{EUR} \mathrm{h}^{-1}\right.$ ) dividing land productivity (EUR $\mathrm{m}^{-2}$ ) by land use intensity $\left(\mathrm{h} \mathrm{m}^{-2}\right)$ predicted by the model. The variability of labor productivity was higher because it integrated both variability of land productivity and land use intensity, respectively linked to the variability of yield and production workload predicted per unit area which were independent for a given scenario and a given cropping cycle (Morel et al., under review). 
Table 1

Characteristics of the crops, yields, production workload, and technical systems involved in MERLIN simulations.

\begin{tabular}{|c|c|c|c|c|c|c|c|c|c|c|c|}
\hline \multirow[t]{2}{*}{ Crop } & \multirow[t]{2}{*}{$\begin{array}{l}\text { Price } \\
\left(\text { EUR } k^{-1}\right)\end{array}$} & \multirow[t]{2}{*}{$\begin{array}{l}\text { Winter } \\
\text { storage } \\
\text { crop* }\end{array}$} & \multirow[t]{2}{*}{$\begin{array}{l}\text { Grown in } \\
\text { tunnels }\end{array}$} & \multirow[t]{2}{*}{$\begin{array}{l}\text { Grown } \\
\text { outdoors }\end{array}$} & \multirow{2}{*}{$\begin{array}{l}\text { Length of the } \\
\text { cropping cycles in } \\
\text { months (min- } \\
\text { max)** }\end{array}$} & \multicolumn{3}{|c|}{$\begin{array}{l}\text { Mean yields in the simulations }\left(\mathrm{kg} \mathrm{m}^{-}\right. \\
\left.{ }^{2}\right)^{* * *}\end{array}$} & \multicolumn{3}{|c|}{$\begin{array}{l}\text { Mean production workload in the } \\
\text { simulations for the running phase }\left(\min \mathbf{m}^{-2}\right. \\
\text { during the cropping cycle)**** }\end{array}$} \\
\hline & & & & & & $\begin{array}{l}\text { Manual } \\
\text { system }\end{array}$ & $\begin{array}{l}\text { Bio- } \\
\text { intensive } \\
\text { system }\end{array}$ & $\begin{array}{l}\text { Classic } \\
\text { system }\end{array}$ & $\begin{array}{l}\text { Manual } \\
\text { system }\end{array}$ & $\begin{array}{l}\text { Bio-intensive } \\
\text { system }\end{array}$ & $\begin{array}{l}\text { Classic } \\
\text { system }\end{array}$ \\
\hline Beetroot (fresh) & 3.0 & & - & - & $4-8$ & $2.7 \pm 1.3$ & $2.8 \pm 1.4$ & $1.9 \pm 0.9$ & $28 \pm 16$ & $21 \pm 11$ & $19 \pm 9$ \\
\hline Beetroot (storage) & 2.6 & - & & - & $4-5$ & $4.3 \pm 2.1$ & $4.5 \pm 2.1$ & $3.2 \pm 1.5$ & $34 \pm 20$ & $26 \pm 14$ & $23 \pm 11$ \\
\hline Broad bean & 4.1 & & $\bullet$ & $\bullet$ & $5-8$ & $2.1 \pm 1$ & $2.2 \pm 1$ & $1.6 \pm 0.8$ & $30 \pm 16$ & $24 \pm 13$ & $20 \pm 9$ \\
\hline Broccoli & 3.6 & & $\bullet$ & $\bullet$ & $4-7$ & $0.8 \pm 0.4$ & $0.8 \pm 0.4$ & $0.6 \pm 0.3$ & $22 \pm 12$ & $17 \pm 9$ & $15 \pm 7$ \\
\hline Brussels sprouts & 4.5 & & & $\bullet$ & $7-9$ & $1.2 \pm 0.6$ & $1.2 \pm 0.6$ & $0.8 \pm 0.4$ & $34 \pm 18$ & $27 \pm 14$ & $23 \pm 11$ \\
\hline Cabbage & 2.5 & & $\cdot$ & $\cdot$ & $5-9$ & $3.8 \pm 1.8$ & $4 \pm 1.9$ & $2.7 \pm 1.3$ & $27 \pm 15$ & $21 \pm 11$ & $18 \pm 9$ \\
\hline Carrot (fresh) & 3.4 & & $\bullet$ & $\bullet$ & $4-8$ & $3.4 \pm 1.6$ & $3.6 \pm 1.7$ & $2.5 \pm 1.2$ & $42 \pm 23$ & $33 \pm 18$ & $28 \pm 13$ \\
\hline Carrot (storage) & 2.4 & $\cdot$ & & $\cdot$ & $5-11$ & $4.4 \pm 2.3$ & $4.5 \pm 2.1$ & $3.2 \pm 1.5$ & $45 \pm 25$ & $37 \pm 22$ & $32 \pm 15$ \\
\hline Cauliflower & 3.0 & & $\bullet$ & $\bullet$ & $4-9$ & $1 \pm 0.5$ & $1 \pm 0.5$ & $0.7 \pm 0.4$ & $23 \pm 13$ & $17 \pm 9$ & $15 \pm 7$ \\
\hline Celeriac (storage) & 3.0 & $\cdot$ & $\cdot$ & $\bullet$ & $5-9$ & $2.7 \pm 1.3$ & $2.9 \pm 1.4$ & $2 \pm 1$ & $30 \pm 17$ & $24 \pm 13$ & $20 \pm 10$ \\
\hline Celery & 2.6 & & $\bullet$ & $\bullet$ & $4-7$ & $2.6 \pm 1.3$ & $2.8 \pm 1.3$ & $1.9 \pm 1$ & $25 \pm 15$ & $20 \pm 10$ & $17 \pm 7$ \\
\hline Chard & 2.7 & & $\bullet$ & $\cdot$ & $3-7$ & $2.3 \pm 1.1$ & $2.4 \pm 1.2$ & $1.7 \pm 0.8$ & $26 \pm 14$ & $20 \pm 11$ & $17 \pm 8$ \\
\hline Chicory & 4.5 & & $\bullet$ & $\bullet$ & $3-6$ & $1.5 \pm 0.7$ & $1.5 \pm 0.7$ & $1.1 \pm 0.5$ & $18 \pm 10$ & $13 \pm 7$ & $12 \pm 6$ \\
\hline Chili & 11.3 & & $\bullet$ & & $6-6$ & $0.3 \pm 0.1$ & $0.3 \pm 0.2$ & $0.2 \pm 0.1$ & $31 \pm 16$ & $24 \pm 13$ & $21 \pm 10$ \\
\hline Chinese cabbage & 4.3 & & $\bullet$ & $\bullet$ & $2-4$ & $3 \pm 1.4$ & $3.1 \pm 1.6$ & $2.2 \pm 1$ & $30 \pm 17$ & $23 \pm 13$ & $20 \pm 9$ \\
\hline Cucumber & 3.1 & & $\bullet$ & $\bullet$ & $4-7$ & $6.9 \pm 3.3$ & $7.3 \pm 3.5$ & $5 \pm 2.4$ & $119 \pm 67$ & $93 \pm 50$ & $81 \pm 38$ \\
\hline Eggplant & 3.9 & & $\bullet$ & & $4-7$ & $4.1 \pm 2$ & $4.3 \pm 2.1$ & $3.1 \pm 1.5$ & $52 \pm 30$ & $40 \pm 21$ & $35 \pm 16$ \\
\hline Endive & 5.8 & & & $\bullet$ & $6-7$ & $0.9 \pm 0.4$ & $1 \pm 0.5$ & $0.7 \pm 0.3$ & $36 \pm 20$ & $28 \pm 15$ & $25 \pm 12$ \\
\hline Fennel & 3.7 & & $\bullet$ & $\cdot$ & $2-6$ & $1.8 \pm 0.9$ & $1.8 \pm 0.9$ & $1.3 \pm 0.6$ & $29 \pm 17$ & $22 \pm 12$ & $19 \pm 9$ \\
\hline French bean & 6.9 & & $\bullet$ & $\bullet$ & $3-6$ & $1.7 \pm 0.8$ & $1.8 \pm 0.9$ & $1.3 \pm 0.6$ & $35 \pm 20$ & $27 \pm 14$ & $24 \pm 11$ \\
\hline Garlic (storage) & 6.0 & & $\bullet$ & & $7-7$ & $1.1 \pm 0.6$ & $1.1 \pm 0.5$ & $0.8 \pm 0.4$ & $32 \pm 17$ & $25 \pm 13$ & $21 \pm 10$ \\
\hline Garlic (spring) & 9.2 & & $\bullet$ & $\bullet$ & $5-11$ & $0.9 \pm 0.5$ & $1 \pm 0.5$ & $0.7 \pm 0.3$ & $37 \pm 21$ & $28 \pm 15$ & $25 \pm 12$ \\
\hline Herbs & 5.1 & & $\bullet$ & $\cdot$ & $4-8$ & $1.5 \pm 0.7$ & $1.6 \pm 0.8$ & $1.1 \pm 0.5$ & $30 \pm 17$ & $23 \pm 13$ & $20 \pm 9$ \\
\hline Kale & 4.0 & & $\bullet$ & $\bullet$ & $3-10$ & $1 \pm 0.5$ & $1.1 \pm 0.5$ & $0.7 \pm 0.4$ & $29 \pm 16$ & $23 \pm 12$ & $20 \pm 9$ \\
\hline Kohlrabi & 3.5 & & $\cdot$ & $\cdot$ & $3-6$ & $3.6 \pm 1.7$ & $3.8 \pm 1.8$ & $2.6 \pm 1.2$ & $28 \pm 15$ & $21 \pm 12$ & $18 \pm 8$ \\
\hline Lamb lettuce & 11.8 & & • & - & $2-5$ & $0.9 \pm 0.4$ & $1 \pm 0.5$ & $0.7 \pm 0.3$ & $47 \pm 25$ & $37 \pm 19$ & $32 \pm 15$ \\
\hline
\end{tabular}




\begin{tabular}{|c|c|c|c|c|c|c|c|c|c|c|c|}
\hline \multirow[t]{2}{*}{ Crop } & \multirow[t]{2}{*}{$\begin{array}{l}\text { Price } \\
\left(\text { EUR kg }^{-1}\right)\end{array}$} & \multirow[t]{2}{*}{$\begin{array}{l}\text { Winter } \\
\text { storage } \\
\text { crop* }\end{array}$} & \multirow[t]{2}{*}{$\begin{array}{l}\text { Grown in } \\
\text { tunnels }\end{array}$} & \multirow[t]{2}{*}{$\begin{array}{l}\text { Grown } \\
\text { outdoors }\end{array}$} & \multirow{2}{*}{$\begin{array}{l}\text { Length of the } \\
\text { cropping cycles in } \\
\text { months (min- } \\
\text { max)** }\end{array}$} & \multicolumn{3}{|c|}{$\begin{array}{l}\text { Mean yields in the simulations (kg m } \\
2^{-* * * *}\end{array}$} & \multicolumn{3}{|c|}{$\begin{array}{l}\text { Mean production workload in the } \\
\text { simulations for the running phase ( } \min \mathbf{m}^{-2} \\
\text { during the cropping cycle)**** }\end{array}$} \\
\hline & & & & & & $\begin{array}{l}\text { Manual } \\
\text { system }\end{array}$ & $\begin{array}{l}\text { Bio- } \\
\text { intensive } \\
\text { system }\end{array}$ & $\begin{array}{l}\text { Classic } \\
\text { system }\end{array}$ & $\begin{array}{l}\text { Manual } \\
\text { system }\end{array}$ & $\begin{array}{l}\text { Bio-intensive } \\
\text { system }\end{array}$ & $\begin{array}{l}\text { Classic } \\
\text { system }\end{array}$ \\
\hline Leek & 2.9 & & - & - & $3-11$ & $2.3 \pm 1.1$ & $2.4 \pm 1.1$ & $1.7 \pm 0.8$ & $48 \pm 27$ & $37 \pm 20$ & $33 \pm 16$ \\
\hline Lettuce & 3.2 & & - & - & $1-8$ & $2.4 \pm 1.2$ & $2.6 \pm 1.3$ & $1.8 \pm 0.9$ & $23 \pm 13$ & $18 \pm 9$ & $16 \pm 7$ \\
\hline Melon & 3.5 & & $\bullet$ & & $4-6$ & $3.7 \pm 1.8$ & $3.9 \pm 1.9$ & $2.7 \pm 1.3$ & $32 \pm 17$ & $25 \pm 14$ & $22 \pm 10$ \\
\hline Mixed salad leaves & 11.3 & & - & - & $3-7$ & $0.9 \pm 0.4$ & $0.9 \pm 0.4$ & $0.6 \pm 0.3$ & $41 \pm 24$ & $31 \pm 17$ & $27 \pm 13$ \\
\hline Onion (spring) & 3.7 & & $\bullet$ & $\bullet$ & $4-9$ & $1.8 \pm 0.9$ & $1.9 \pm 0.9$ & $1.3 \pm 0.6$ & $38 \pm 22$ & $30 \pm 16$ & $25 \pm 12$ \\
\hline Onion (storage) & 3.1 & & & - & $4-10$ & $2.4 \pm 1.2$ & $2.6 \pm 1.3$ & $1.8 \pm 0.9$ & $43 \pm 23$ & $33 \pm 18$ & $29 \pm 14$ \\
\hline Parsnip & 3.2 & & & $\bullet$ & $8-11$ & $3.5 \pm 1.8$ & $3.6 \pm 1.7$ & $2.5 \pm 1.3$ & $41 \pm 22$ & $31 \pm 17$ & $28 \pm 13$ \\
\hline Pea & 7.7 & & - & $\bullet$ & $2-7$ & $1.1 \pm 0.5$ & $1.1 \pm 0.5$ & $0.8 \pm 0.4$ & $41 \pm 23$ & $31 \pm 17$ & $27 \pm 13$ \\
\hline Potato (storage) & 2.1 & $\bullet$ & $\bullet$ & $\bullet$ & $4-6$ & $2.3 \pm 1.1$ & $2.4 \pm 1.2$ & $1.7 \pm 0.8$ & $38 \pm 21$ & $30 \pm 17$ & $26 \pm 13$ \\
\hline Potato (early) & 3.5 & & & $\bullet$ & $6-7$ & $2.7 \pm 1.3$ & $2.8 \pm 1.4$ & $2 \pm 1$ & $41 \pm 22$ & $31 \pm 16$ & $27 \pm 12$ \\
\hline Radish (fresh) & 4.9 & & $\bullet$ & $\bullet$ & $2-7$ & $1.6 \pm 0.8$ & $1.7 \pm 0.9$ & $1.2 \pm 0.6$ & $27 \pm 15$ & $21 \pm 11$ & $19 \pm 9$ \\
\hline Radish (storage) & 2.9 & & $\bullet$ & $\bullet$ & $3-6$ & $3 \pm 1.4$ & $3.1 \pm 1.5$ & $2.1 \pm 1$ & $23 \pm 13$ & $18 \pm 10$ & $15 \pm 7$ \\
\hline Shallot (storage) & 5.7 & & $\bullet$ & - & $2-8$ & $1.5 \pm 0.7$ & $1.5 \pm 0.8$ & $1.1 \pm 0.5$ & $37 \pm 21$ & $29 \pm 16$ & $25 \pm 11$ \\
\hline Spinach & 4.7 & & $\bullet$ & - & $2-7$ & $1 \pm 0.5$ & $1 \pm 0.5$ & $0.7 \pm 0.3$ & $38 \pm 20$ & $29 \pm 16$ & $25 \pm 11$ \\
\hline Squash & 2.6 & & $\bullet$ & $\bullet$ & $5-7$ & $3.3 \pm 1.6$ & $3.4 \pm 1.7$ & $2.4 \pm 1.2$ & $24 \pm 14$ & $19 \pm 10$ & $16 \pm 8$ \\
\hline Strawberry & 10.5 & & & $\bullet$ & $2-2$ & $1.4 \pm 0.7$ & $1.5 \pm 0.7$ & $1 \pm 0.5$ & $41 \pm 22$ & $32 \pm 17$ & $28 \pm 13$ \\
\hline Sweede (storage) & 2.6 & $\bullet$ & & - & $7-8$ & $3.4 \pm 1.6$ & $3.6 \pm 1.8$ & $2.5 \pm 1.2$ & $23 \pm 12$ & $18 \pm 10$ & $16 \pm 7$ \\
\hline Sweet pepper & 4.5 & & $\bullet$ & $\bullet$ & $4-7$ & $3.4 \pm 1.5$ & $3.6 \pm 1.7$ & $2.5 \pm 1.2$ & $43 \pm 24$ & $33 \pm 19$ & $28 \pm 13$ \\
\hline Tomato (cherry) & 6.6 & & - & & $5-8$ & $6.4 \pm 3$ & $6.7 \pm 3.3$ & $4.6 \pm 2.3$ & $128 \pm 71$ & $96 \pm 52$ & $84 \pm 40$ \\
\hline Tomato (classic) & 3.1 & & $\bullet$ & & $5-7$ & $11.6 \pm 5.8$ & $12.3 \pm 6$ & $8.6 \pm 4.1$ & $126 \pm 71$ & $99 \pm 53$ & $85 \pm 40$ \\
\hline Tomato (heritage) & 3.9 & & $\bullet$ & & $5-7$ & $6.5 \pm 3.2$ & $6.8 \pm 3.3$ & $4.7 \pm 2.2$ & $126 \pm 71$ & $98 \pm 53$ & $86 \pm 40$ \\
\hline Turnip (fresh) & 3.2 & & $\bullet$ & $\bullet$ & $2-7$ & $2.8 \pm 1.4$ & $3 \pm 1.4$ & $2 \pm 1$ & $27 \pm 15$ & $21 \pm 11$ & $18 \pm 9$ \\
\hline Turnip (storage) & 2.6 & $\bullet$ & & $\bullet$ & $4-5$ & $3.5 \pm 1.7$ & $3.6 \pm 1.7$ & $2.6 \pm 1.3$ & $23 \pm 13$ & $18 \pm 10$ & $15 \pm 7$ \\
\hline Zucchini & 2.6 & & $\bullet$ & $\bullet$ & $3-7$ & $5.3 \pm 2.6$ & $5.6 \pm 2.7$ & $3.8 \pm 1.8$ & $32 \pm 18$ & $25 \pm 13$ & $22 \pm 10$ \\
\hline
\end{tabular}

*Winter storage crops were only grown in the 12-month marketing strategy.

**The length of the cropping cycles depended on the time of the year, the climate, and tunnel or outdoor location. The 1053 possible cropping cycles with their planting and harvesting periods are described in Morel (2016; pp. 290-317).

***Yields are given per unit of cultivated acreage excluding footpaths. Climate and location did not affect yields but did affect possible cropping cycles during the year (crops could start earlier in the mild climate or in tunnels).

****Production workload does not include commercial and administrative tasks, which were factored in to assess viability (20\% of annual workload). Production workload is given per unit of cultivated acreage excluding footpaths for the running phase. 

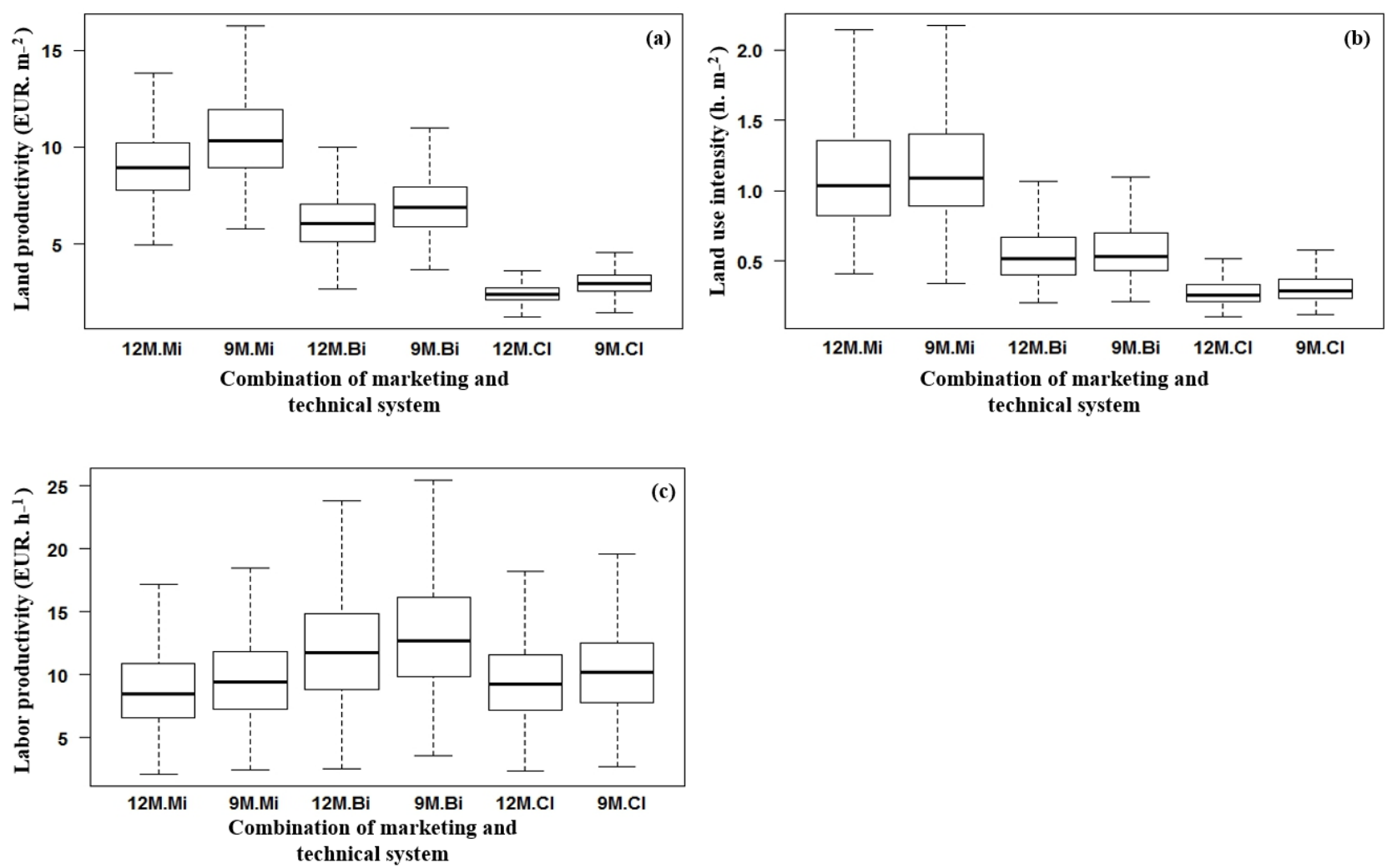

Fig. 3. Effect of marketing and technical system on (a) land productivity, (b) land-use intensity, and (c) labor productivity. Marketing strategy: 12M, 12-month marketing strategy including winter storage crops; 9M, 9-month marketing strategy excluding winter storage crops. Technical system: Mi, manual system; Bi, bio-intensive system; $\mathrm{Cl}$, classic system. The mean levels of all combinations were judged different by the crossed t-tests (5\%) corrected with the FDR approach.

\subsection{Viability according to the simulated scenarios}

For a given scenario, the level of viability varied within the constraints associated with each scenario (Table 2). The bio-intensive system had the highest labor productivity (Fig.3) and low costs attributable to low-cost practices. This explains why the bio-intensive system led to higher viability than other technical systems. The manual and classic systems had close levels of labor productivity, but the former had lower variable and fixed costs than the latter, which resulted in higher viability for the manual system.

The setup phase was more risky (lower viability) than the running phase, regardless of whether low-cost or high-cost setup was used. However, as the manual and bio-intensive systems required less UAA (Fig.4) and less equipment, they incurred lower bank loans than the classic system, and therefore had greater viability during the setup phase. The high-cost setup had, on average, higher viability than the low-cost setup, indicating that the reduced costs of low-cost setup scenarios were not sufficient to mitigate the increased workload associated with self-built equipment.

The 9-months marketing strategy led to higher viability than the 12-months marketing strategy due to higher labor productivity in the former. This increase in viability was associated with a higher average share of tunnels in the UAA for the 9-months strategy than in the 12- 
months strategy ( $32 \pm 5 \%$ versus $22 \pm 4 \%$, respectively). In the 9-months strategy, the farmer had to generate enough sales during the shorter marketing period when the demand for tunnel crops was high (e.g., tomatoes, sweet peppers, cucumbers, and eggplants). This explained the higher share of tunnels in the 9-months strategy. The positive outcome of this marketing strategy was less pronounced in the high-cost setup than in the low-cost setup because the larger share of tunnels increased the setup investment costs, which had a greater effect on scenarios where tunnels were purchased rather than built by the farmer.

On average, the two climates did not affect viability. The cold climate required a higher share of tunnels in UAA than the mild climate (30 $\pm 1 \%$ versus $24 \pm 1 \%$, respectively) which raised investment costs. These costs were mitigated by the fact that crops grown in tunnels (Table 1) generated more sales per unit area than those grown outdoors $\left(10.0 \pm 6.85\right.$ EUR m$^{-2}$ versus $7.2 \pm 2.4 \mathrm{EUR} \mathrm{m}^{-2}$, respectively).

Table 2

Viability for each scenario according to the initial constraints of income and workload.

\begin{tabular}{|c|c|c|c|c|c|c|c|c|}
\hline \multirow[b]{3}{*}{$\begin{array}{l}\text { Maximum } \\
\text { annual } \\
\text { workload } \\
\text { (h) }\end{array}$} & \multirow[b]{3}{*}{$\begin{array}{l}\text { Minimum } \\
\text { monthly } \\
\text { income } \\
\text { (EUR) }\end{array}$} & \multirow[b]{3}{*}{$\begin{array}{l}\text { Investment } \\
\text { hypothesis }\end{array}$} & \multicolumn{6}{|c|}{ Technical system } \\
\hline & & & \multicolumn{2}{|l|}{ Manual } & \multicolumn{2}{|l|}{ Bio-intensive } & \multicolumn{2}{|l|}{ Classic } \\
\hline & & & $\begin{array}{l}\text { Share of } \\
\text { viable } \\
\text { simulations } \\
\text { for } 12 \mathrm{M} \\
(\%) \\
\end{array}$ & $\begin{array}{l}\text { Share of } \\
\text { viable } \\
\text { simulations } \\
\text { for } 9 \mathrm{M}(\%)\end{array}$ & $\begin{array}{l}\text { Share of } \\
\text { viable } \\
\text { simulations } \\
\text { for } 12 \mathrm{M} \\
(\%)\end{array}$ & $\begin{array}{l}\text { Share of } \\
\text { viable } \\
\text { simulations } \\
\text { for } 9 \mathrm{M}(\%)\end{array}$ & $\begin{array}{l}\text { Share of } \\
\text { viable } \\
\text { simulations } \\
\text { for } 12 \mathrm{M} \\
(\%)\end{array}$ & $\begin{array}{l}\text { Share of } \\
\text { viable } \\
\text { simulations } \\
\text { for } 9 \mathrm{M}(\%)\end{array}$ \\
\hline \multirow{3}{*}{2,500} & \multirow{3}{*}{600} & $\mathrm{LS}$ & 30 & 39 & 34 & 41 & 0 & 1 \\
\hline & & HS & 59 & 64 & 55 & 50 & 1 & 1 \\
\hline & & $\mathrm{R}$ & 95 & 97 & 98 & 100 & 82 & 89 \\
\hline \multirow{3}{*}{1,800} & \multirow{3}{*}{600} & LS & 5 & 8 & 7 & 11 & 0 & 0 \\
\hline & & HS & 21 & 24 & 18 & 19 & 0 & 0 \\
\hline & & $\mathrm{R}$ & 67 & 69 & 87 & 94 & 40 & 53 \\
\hline \multirow{3}{*}{2,500} & \multirow{3}{*}{1,000} & $\mathrm{LS}$ & 6 & 9 & 10 & 16 & 0 & 0 \\
\hline & & HS & 28 & 31 & 29 & 28 & 0 & 0 \\
\hline & & $\mathrm{R}$ & 70 & 82 & 90 & 96 & 51 & 64 \\
\hline \multirow{3}{*}{1,800} & \multirow{3}{*}{1,000} & $\overline{L S}$ & 0 & 1 & 0 & 2 & 0 & 0 \\
\hline & & HS & 5 & 6 & 5 & 6 & 0 & 0 \\
\hline & & $\mathrm{R}$ & 29 & 39 & 59 & 70 & 13 & 19 \\
\hline \multirow{3}{*}{2,500} & \multirow{3}{*}{1,400} & $\mathrm{LS}$ & 1 & 1 & 3 & 5 & 0 & 0 \\
\hline & & HS & 10 & 12 & 13 & 14 & 0 & 0 \\
\hline & & $\mathrm{R}$ & 41 & 53 & 74 & 82 & 23 & 33 \\
\hline \multirow{3}{*}{1,800} & \multirow{3}{*}{1,400} & $\mathrm{LS}$ & 0 & 0 & 0 & 0 & 0 & 0 \\
\hline & & HS & 1 & 1 & 1 & 1 & 0 & 0 \\
\hline & & $\mathrm{R}$ & 8 & 14 & 31 & 41 & 3 & 5 \\
\hline
\end{tabular}

Investment hypothesis: LS, low-cost setup; HS, high-cost setup; R, running phase.

Marketing strategy: 12M, 12-month marketing strategy including winter storage crops; 9M, 9-month marketing strategy excluding winter storage crops.

Darker shades of gray indicate higher viability of the scenario.

All modalities of technical system, investment, marketing, maximal annual workload, minimal monthly income had a significant impact on viability chances (5\%) as highlighted by the forward selection procedure of a GLM 
model. The climate had no impact. The chances of success for the classic system were most of the time nonexistent during the setup phase (LS or HS) due to the higher initial investment required and resulting bank loans. This 2way interaction between technical system and investment was statistically significant in the GLM (5\%).

\subsection{Utilized agricultural area of viable simulations}

The UAA of viable simulations is illustrated in Fig. 4. The resulting UAA was smallest in the manual system and highest in the classic system, which was consistent with the relative land productivity of each system (Fig.3). Higher land productivity supports lower required acreage for viability. On average, the UAA was lower in viable low-cost setup scenarios than in the running phase, and higher in high-cost setup scenarios than in the running phase. In low-cost setup scenarios, workload was dedicated to building the equipment to be used on the farm, which limited the acreage that could be cultivated, whereas this workload could be used to cultivate more acreage in the high-cost setup scenarios, which contributed to the repayment of the bank loans.

The classic system relied on the highest average acreage in tunnels compared with the manual and bio-intensive systems $\left(2068 \pm 335 \mathrm{~m}^{2}\right.$ versus $728 \pm 137 \mathrm{~m}^{2}$ versus $1501 \pm 286 \mathrm{~m}^{2}$, respectively). For all three technical systems, tunnel areas led to higher land productivity than outdoor areas. However, the manual and bio-intensive systems had higher land productivity outdoors than the classic system, which was consistent with their higher land-use objectives. This explained why these systems had relatively higher shares of tunnels compared with their global UAA ( $29 \pm 3 \%$ for the manual system, $31 \pm 2 \%$ for the bio-intensive system, and $19 \pm$ $10 \%$ for the classic system). 


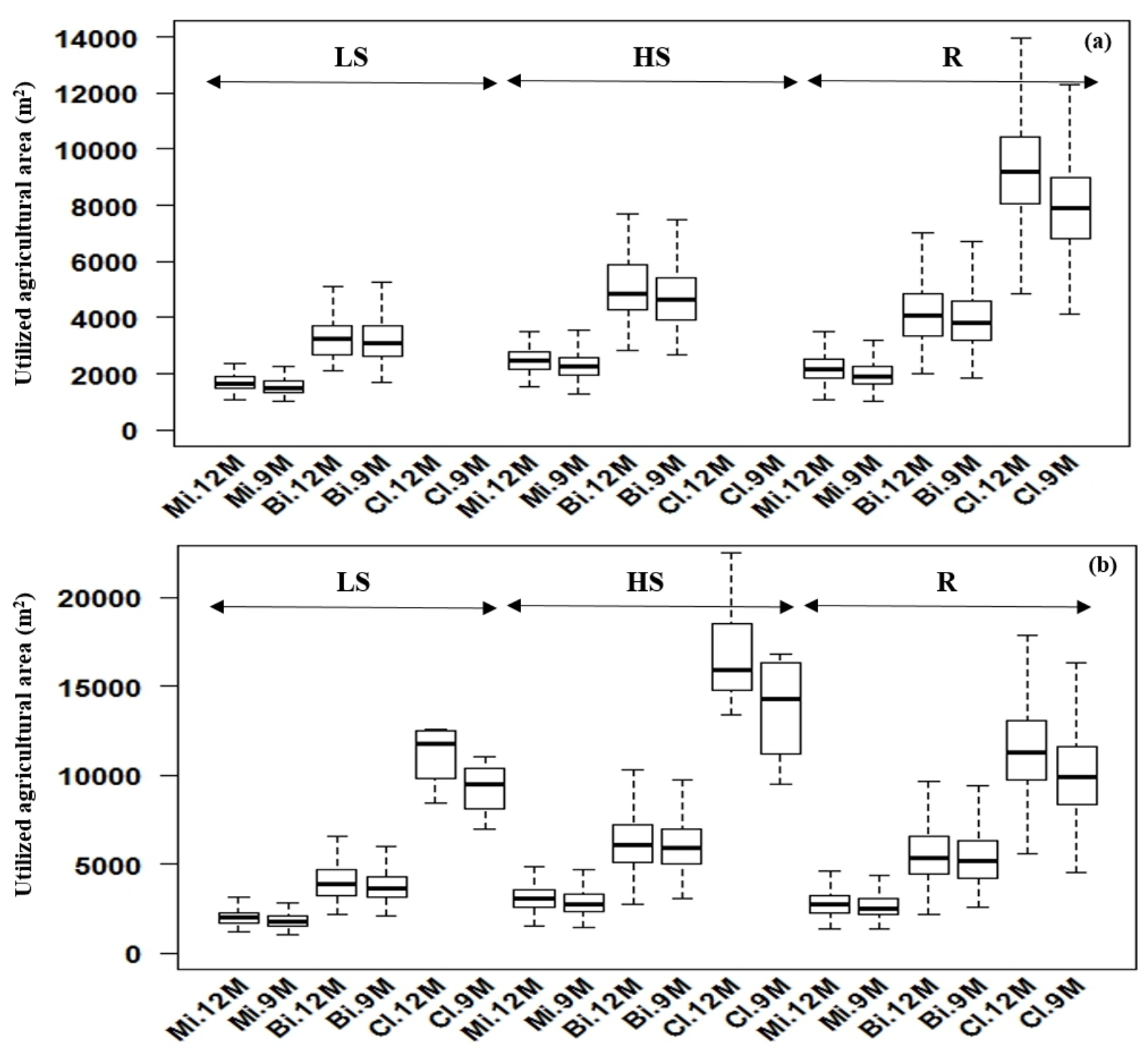

Scenarios (combination of technical system and marketing on the $x$-axis and investment hypothesis above)

Fig. 4. Utilized agricultural area $\left(\mathrm{m}^{2}\right)$ for viable simulations according to the scenarios for an annual workload of (a) 1,800 h and (b) 2,500 h. Investment hypothesis: LS, low-cost setup; HS, high-cost setup; R, running phase. Marketing strategy: 12M, 12-month marketing strategy including winter storage crops; 9M, 9-month marketing strategy excluding winter storage crops. Technical system: Mi, manual system; $\mathrm{Bi}$, bio-intensive system; $\mathrm{Cl}$, classic system. Absence of boxplot indicates no viable simulations for this scenario. The mean levels of all combinations were judged different by the crossed t-tests $(5 \%)$ corrected with the FDR approach.

\section{DISCUSSION}

\subsection{Main conclusions and credibility of the modelling outputs}

Our study showed that in some cases organic microfarms could be economically viable but that their viability chances varied strongly according to the levels of income and workload accepted by farmers. Viability chances were high for running farms accepting a monthly income of $600 €$. For microfarmers targeting an income greater than or equal to the French minimal salary (1,000 EUR) viability was more difficult to reach, especially with the most ambitious workload objective of $1,800 \mathrm{~h}$ per year. This study highlighted that the risks of not reaching viability in microfarms were not to be neglected. However, it refuted the dominant idea in 
French agricultural institutions that it was impossible to be economically viable on a microfarm. To broaden the perspectives on microfarm viability, simulations should be conducted for larger organic and conventional market gardens, and the resulting viabilities should be compared with those of microfarms considering that viability is never guaranteed in farming, even in larger or conventional farms.

Our model revealed that marketing and investment strategies have key roles in determining microfarm viability, whereas most information and public debate about microfarms focus primarily on technical aspects. Although the manual and bio-intensive systems have greater viability than the classic system during the setup phase because they require lower initial investment, viability is not likely to be achieved during the setup phase (assuming that the farmer does not have the initial capital). These results provide a crucial warning for optimistic young microfarmers who may underestimate the difficulties and uncertainties, inherent in farming. These new farmers often choose to self-build their equipment out of second-hand material to limit the farm's dependence on bank loans and commercial companies. However, MERLIN showed that this practice reduced viability because of the higher workload required for self-building activities. These results may dampen idealistic do-it-yourself approaches in alternative farmers' networks, and suggests that alternative or extra sources of income during the crucial setup phase would help to increase long-term viability.

The outputs of this application of MERLIN have been presented to practitioners in 30 occasions including organic agriculture shows and workshops with farmers. They have globally been judged credible by more than 400 farmers, agricultural teachers and advisors. Feedbacks from the field were integrated in the following discussion points.

\subsection{For microfarms, system redesign works better that input substitution.}

In industrialized countries, the conventionalization of organic farming based on input substitution rather than system redesign is receiving increasing criticism (Rosset and Altieri, 1997; Darnhofer et al., 2010).

The classic technical system implements input substitution because it relies on commercial inputs and is similar to conventional market gardens in terms of mechanization. However, the high number of crops grown on the farm (from 30 to 50) is an attempt to promote biological diversity and reduce phytosanitary risks, which is the first step of a redesign approach. The manual and bio-intensive systems go further in terms of global redesign. If they equally rely on a high level of cultivated biodiversity, they implement low-input practices to limit their dependency on commercial inputs (including fuel). These low-input practices require higher workload (e.g., straw mulching, composting, preparing farm-made phytosanitary preparations and propagating plants), which could be considered as substitution of inputs with labor. However, this increase in workload is mitigated by other strategies such as high cropping density and intercropping, which limits weeding, increase yields, requires less frequent and more superficial soil tillage, and smaller costs associated with lower mechanization levels. The coherent small-scale approaches of manual and bio-intensive systems can be considered as a global redesign compared with conventional market gardening. 
This study shows that global redesign based on low mechanization (manual and biointensive systems) can be more viable on smaller acreage than input substitution.

\subsection{How to make small more successful?}

Our study focused on a limited set of possible contrasted strategic scenarios. However, discussions with microfarmers based on the modelling outputs suggested various perspectives to increase the economic viability of microfarms.

Scenarios could be developed considering different technical systems for different crops on the same farm. For example, some microfarms chose to implement manual labor on crops with high added value that are produced in small quantities, and mechanized labor for crops with low added value that are produced in bigger quantities. Innovative technical strategies implemented by some microfarmers, such as no-tillage and conservation agriculture applied to market gardening, could be explored further using MERLIN. Moreover, the microfarms used to calibrate the model were relatively young (from 2 to 9 years). As the growing of a high diversity of crops and the implementation of low input practices require a high level of technicity and know-how, viability may also increase with the experience of farmers. Carrying out the same study based on data coming from more experienced farmers may be an interesting perspective for the future. It may prove than such complex systems are highly skill dependent which could encourage new microfarmers to get better training and experience before starting their own farm.

Some microfarmers also may sell part of their harvest at higher prices that in this study through other short supply chains, for example to restaurants or premium organic shops. Scenarios with higher prices for some or part of the crops should be investigated because they could increase viability.

Our work considered constraining scenarios with a single rural farmer whose entire labor was paid from the farm income, and with no initial capital. In reality, some microfarmers employ volunteers or trainees in exchange for sharing their skills and some material advantages (food and accommodation). Some microfarmers have accumulated a small capital from their previous careers and activities, which could be used to reduce bank loans and mutualize some tasks or equipment with other farmers ([on the farm as an associate or in the neighborhood] through collaborative structures and networks). Building other modeling scenarios could enable the exploration of all these dimensions, but would require the initial collection of extensively more data.

\subsection{From economic viability to sustainability}

We assessed economic viability based on a quantification of incomes and annual workloads. In CSA schemes, long-term economic viability is strongly dependent on customer satisfaction. Although the 9-monts marketing strategy was more profitable, it might not be as effective as the 12-months strategy in maintaining customer loyalty. CSA customers may want winter storage crops and reject a supplier that does not supply vegetables from January to March. The 9-months strategy also relies on sales concentrated over a shorter marketing period, which could 
lead to workload peaks considered as a constraint for farmers. Microfarmers may have to find trade-offs between these two strategies, or at least should be aware of the advantages and disadvantages of each strategy.

More qualitative aspects of labor should be considered in addition to quantification of workload peaks during the year, such as work hardness and associated sustainability (e.g., related to different levels of mechanization) (Fiorelli et al., 2010), capacity to take holidays and week-ends off, and general level of happiness at work. For a wider assessment of the sustainability associated with different scenarios, the model should integrate wider social and environmental indicators, such as the effect on local employment (in terms of jobs created per unit surface area by small farms), greenhouse gases, energy consumption related to peat-based compost used by most microfarmers to propagate their plants and other inputs, biodiversity, and water quality. Further development could rely on existing sustainable frameworks (Hansen and Jones, 1996; Darnhofer et al., 2010), life cycle analysis (Markussen et al., 2014), and discussions of the modeling outputs with farmers in participatory workshops, especially for the more subjective aspects (Martin et al., 2013).

\section{CONCLUSION: WHAT FUTURES FOR MICROFARMS?}

In industrialized countries, microfarms are developing both as a response to the subjective aspiration of a new generation of practitioners to farm at a "human scale", to "live a better life", to "reconnect to nature" as well as a pragmatic alternative to the growing difficulty in accessing land and financial capital required to create or take over larger farms. Although their chances of failure do not have to be neglected, especially during the setting up of the farm, this work shows that adapted technical, marketing and investment strategies can make possible for farmers to be viable despite the constraint of a small scale. It contributes to the existing scientific literature indicating that it is possible for small farms to be economically successful whereas the dominant agricultural model encourages an increase in size (Carter, 1984; Cornia, 1985; USDA, 1998; Rosset, 2000).

In and around cities of industrialized countries, microfarms are becoming increasingly popular because they can squeeze into small plots of available land while being in line with the political agenda of more and more cities to develop as much as possible locally produced food for urban populations. However, even in the theoretical hypothesis of a dense "green belt" of microfarms in suburban areas which may provide a significant part of local needs in fresh vegetables, supplying the whole diet of big cities would require to associate farming systems on a larger scale (e.g. for meat, cereals, milk). The possible collaboration and competition between urban and larger more distant farms to feed cities must be further examined. This study focused on rural scenarios which may not easily match the reality of urban farming. Urban contexts could strongly modify the modelling hypotheses, affecting for example costs to access land and resources, prices, marketing strategies and lead to various specific constraints and opportunities. For many urban microfarms, creation of social links between inhabitants, pedagogical activities or other types of social work are at least as important as food production (Daniel, 2017). This adds a lot of factors to be considered about the viability of urban microfarms going far beyond the scope of our model. Nevertheless, our work could be used to 
generate discussions with practitioners about the productive dimension of urban microfarms. Reactions and critics of urban microfarmers to our rural scenarios could be the first step of an adaptation of the MERLIN model to urban farming.

In rural areas, a minority of microfarmers argue that the intensification of the production per unit area promoted by the manual and the bio-intensive system could be a way to preserve natural ecosystems or promote biodiversity. Echoing the hypothesis of Borlaug (2007) and the logic of "land sparing" (Fisher et al., 2014), they would suggest that on a plot of 15,000 $\mathrm{m}^{2}$ which is recommended for classic diversified market gardening in France, a microfarmer could make a living while producing vegetables intensively on $5,000 \mathrm{~m}^{2}$. This would leave the left $10,000 \mathrm{~m}^{2}$ for biodiversity conservation actions. For these microfarmers, who do not want to increase area, surplus incomes may be used to progressively raise the share of tunnels, with less and less open land, in order to maximize land productivity. The maximum share of tunnels to guarantee the high levels of biodiversity, aesthetics and material autonomy (fertility reproduction) that microfarmers often seek rather than profit maximization (Morel and Léger, 2016) needs to be investigated. The ecological consequences of such intensification practices would require specific research, encompassing potential negative impacts (e.g on nitrogen surpluses).

For most rural microfarmers, intensification on a small plot is not implemented for ecological reasons but mainly as a pragmatic way to start a farming activity on a small plot with little financial capital and no agricultural background. From this initial "entering point" in the agricultural world, some of them wish to progressively invest surplus incomes in developing new areas that would be dedicated to fertility reproduction and material autonomy, improve biological regulation, create more heterogeneous and pleasant landscapes, diversify the sources of income, create more jobs (e.g., areas for green manure, wildlife habitats, small-scale breeding, and production of fruit, mushrooms and honey). These future complex farming systems may be not market gardening microfarms any longer but may develop into wider complex ecosystems of different micro-activities. Such possible evolutions would justify a more dynamic study of microfarms.

In the agricultural context of industrialized countries where farms tend to get bigger and bigger, microfarms may seem to be anecdotic and utopic initiatives whose contribution to the required agroecological transition of agriculture is be limited. Nevertheless, while allowing a new generation of farmers with alternative ideas and worldviews to access agriculture, they may contribute to change the mentalities of "historic" farmers. In Europe, a growing number of large scale cattle breeders or cereal growers (even if still a minority) are starting to consider seriously the potential of microfarming to create more jobs and added value per unit area and bring young people back to the countryside. These farmers allow microfarmers to rent a plot of their land to set up their activity which can lead to collaborations that seem to be beneficial for both sides. Young microfarmers with no agricultural background can learn a lot from historic farmers about soils, climate, local context and access to resources that historic farmers mutualize with them (such as tractors, storage buildings, straw for mulching, cattle manure). Inspired by 
microfarmers, historic farmers are stimulated to make their farming practices evolve toward more production diversity, agroecological practices, on farm processing (e.g. cheese and bread) and the development of short supply chains. Some of them mutualize the distribution and selling of their produce with microfarmers which enables them to access local markets that they would less easily access without the presence of fresh vegetables which attract consumers. Such fruitful collaborations must not be idealized and their development may be threatened by numerous social, commercial, cultural and technical difficulties and locks-in. Further research needs to be carried out to examine how and in which extent new partnerships between newly arrived microfarmers and historic farmers may reshape farming systems and impact rural communities beyond the gate of microfarms.

\section{ACKNOWLEDGEMENTS}

We thank all the farmers who dedicated time and energy for this research project. We also thank the Ile-de-France Region for financial support for this work through DIM ASTREA; Agnes Bellec-Gauche for her accountancy skills; and Rodolphe Sabatier and Guillaume Martin for their constructive feedback and support.

\section{REFERENCES}

Allens, G. d', Leclair, L., 2016. Les néo-paysans. Éditions du Seuil, DL 2016, Paris, France. Aubin, J.-P., 1991. Viability theory. Systems \& control: Foundations \& applications. Birkhäuser Boston Doi 10, 978-0.

Benjamini, Y., Hochberg, Y., 1995. Controlling the False Discovery Rate: A Practical and Powerful Approach to Multiple Testing. J. R. Stat. Soc. Ser. B Methodol. 57, 289-300.

Borlaug, N., 2007. Feeding a Hungry World. Science 318, 359-359. doi:10.1126/science.1151062

Carter, M.R., 1984. Identification of the inverse relationship between farm size and productivity: an empirical analysis of peasant agricultural production. Oxf. Econ. Pap. 36, 131-145.

Coleman, E., 1995. The New Organic Grower: A Master's Manual of Tools and Techniques for the Home and Market Gardener, 2nd Edition, Revised and expanded second edition, ed. Chelsea Green Publishing, White River Junction, Vt.

Cornia, G.A., 1985. Farm size, land yields and the agricultural production function: An analysis for fifteen developing countries. World Dev. 13, 513-534.

Daniel, A.C., 2017. Fonctionnement et durabilité des microfermes urbaines, une observation participative sur le cas des fermes franciliennes. Chaire Eco-conception, AgroParisTech, INRA, UMR SADAPT, France. http://www.cityfarmer.org/2017DanielACD.pdf (accessed March 20, 2017)

Darnhofer, I., Lindenthal, T., Bartel-Kratochvil, R., Zollitsch, W., 2010. Conventionalisation of organic farming practices: from structural criteria towards an assessment based on organic principles. A review. Agron. Sustain. Dev. 30, 67-81.

doi:10.1051/agro/2009011 
De Liedekerke De Pailhe, A., 2004. Designing intecropping in vegetables, scope for improvements. A case study implemented at Bec Hellouin Farm, Normandy, France. Master thesis in Organic Agriculture and Agroecolology. ISARA Lyon, France and Wageningen University, Nl.

http://www.fermedubec.com/inra/2014\%2009\%20Rapport\%20de\%20stage\%20Alexis\% 20de\%20Liedekerke\%20-\%20Associations\%20de\%20cultures.pdf (accessed August 15, 2016)

Eisenhardt, K.M., 1989. Building theories from case study research. Acad. Manage. Rev. 14, 532-550.

Fernandez, M., Goodall, K., Olson, M., Méndez, V.E., 2013. Agroecology and Alternative Agri-Food Movements in the United States: Toward a Sustainable Agri-Food System. Agroecol. Sustain. Food Syst. 37, 115-126. doi:10.1080/10440046.2012.735633

Fiorelli, C., Porcher, J., Dedieu, B., 2010. Identifier les ajustements faits par les éleveurs pour organiser leur travail et comprendre leur sens. Journ. D'études INRAD-CIRAD Trav. En Agric. Dans Sci. Pour L'action 231-243.

Fischer, J., Abson, D.J., Butsic, V., Chappell, M.J., Ekroos, J., Hanspach, J., Kuemmerle, T., Smith, H.G., von Wehrden, H., 2014. Land Sparing Versus Land Sharing: Moving Forward. Conserv. Lett. 7, 149-157. doi:10.1111/conl.12084

Fortier, J.-M., 2014. The Market Gardener: A Successful Grower's Handbook for Small-scale Organic Farming. New Society Publishers, Place of publication not identified.

GRAB/FRAB, Fédération Nationale d'Agriculture Biologique (2009). S'installer en maraîchage bio. Fiches techniques Fruits et Légumes n¹7. http://www.agrobiobretagne.org/wp-content/uploads/2010/09/Installation.pdf (accessed July 23, 2016)

Hansen, J.W., Jones, J.W., 1996. A systems framework for characterizing farm sustainability. Agric. Syst. 51, 185-201. doi:10.1016/0308-521X(95)00036-5

Hervé-Gruyer, P., Hervé-Gruyer, C., 2016. Miraculous Abundance: One Quarter Acre, Two French Farmers, and Enough Food to Feed the World. Chelsea Green Publishing.

Holt Giménez, E., Shattuck, A., 2011. Food crises, food regimes and food movements: rumblings of reform or tides of transformation? J. Peasant Stud. 38, 109-144. doi:10.1080/03066150.2010.538578

Jeunes Agriculteurs. 2013. Enquête nationale sur les hors cadres familiaux en agriculture, qui sont-ils et quels sont leurs besoins ? http://www.jeunes-agriculteurs.fr/deveniragriculteur/item/677-demain-je-serai-paysan-?-etat-des-lieux-des-installations-des-horscadres-familiaux (accessed October 10, 2015)

Liebman, M., Davis, A.S., 2000. Integration of soil, crop and weed management in lowexternal-input farming systems. WEED Res.-Oxf.- 40, 27-48.

Lovell, S.T., 2010. Multifunctional urban agriculture for sustainable land use planning in the United States. Sustainability 2, 2499-2522.

Markussen, M.V., Kulak, M., Smith, L.G., Nemecek, T., Østergla ard, H., 2014. Evaluating the Sustainability of a Small-Scale Low-Input Organic Vegetable Supply System in the United Kingdom. Sustainability 6, 1913-1945.

Martin, G., Martin-Clouaire, R., Duru, M., 2013. Farming system design to feed the changing world. A review. Agron. Sustain. Dev. 33, 131-149. doi:10.1007/s13593-011-0075-4 
Martin, G., Theau, J.-P., Therond, O., Martin-Clouaire, R., Duru, M., 2011. Diagnosis and Simulation: a suitable combination to support farming systems design. Crop Pasture Sci. 62, 328-336.

Milan Urban Food Policy Pack (2016). http://www.milanurbanfoodpolicypact.org (accessed September 13, 2016)

Mollison, B., Holmgren, D., 1981. Permaculture One: A Perennial Agriculture for Human Settlements, 1ST edition. ed. International Tree Crop Institute USA, U.S.

Morel, K., 2016. Viabilité des microfermes maraîchères biologique. Une étude inductive combinant méthodes qualitatives et modélisation. PhD Dissertation. UMR SADAPT, INRA, AgroParisTech, University Paris-Saclay. http://prodinra.inra.fr/record/387244 (accessed September 14, 2016)

Morel, K., Léger, F., 2016. A conceptual framework for alternative farmers' strategic choices: the case of French organic market gardening microfarms. Agroecol. Sustain. Food Syst. 40, 466-492. doi:10.1080/21683565.2016.1140695

Morel, K., San Cristobal, M., Léger, F., (under review). Simulating incomes of radical organic farms with MERLIN: A grounded modeling approach for French microfarms. Manuscript under review for the Agricultural Systems (ref: AGSY_2016_465)

Rosset, P., 2000. The multiple functions and benefits of small farm agriculture in the context of global trade negotiations. Development 43, 77-82.

Rosset, P.M., Altieri, M.A., 1997. Agroecology versus input substitution: A fundamental contradiction of sustainable agriculture. Soc. Nat. Resour. 10, 283-295. doi:10.1080/08941929709381027

Schumacher, E.F., 1989. Small Is Beautiful: Economics as if People Mattered. Harper Perennial, New York.

Stoate, C., Báldi, A., Beja, P., Boatman, N.D., Herzon, I., van Doorn, A., de Snoo, G.R., Rakosy, L., Ramwell, C., 2009. Ecological impacts of early 21st century agricultural change in Europe - A review. J. Environ. Manage. 91, 22-46.

doi:10.1016/j.jenvman.2009.07.005

USDA, United States Department of Agriculture, 1998. A Time to Act: A Report of the USDA National Commission on Small Farms. Washington DC: USDA Miscellaneous Publication 1545.

Van Der Ploeg, J.D., 2010. The Food Crisis, Industrialized Farming and the Imperial Regime. J. Agrar. Change 10, 98-106. doi:10.1111/j.1471-0366.2009.00251.x 